\title{
Butterfly Pea Flower (Clitoria ternatea Linn.) Extract Ameliorates Cardiovascular Dysfunction and Oxidative Stress in Nitric Oxide-Deficient Hypertensive Rats
}

\author{
Putcharawipa Maneesai ${ }^{1} \oplus$, Metee Iampanichakul ${ }^{1}$, Nisita Chaihongsa ${ }^{1}$, Anuson Poasakate ${ }^{1}$, Prapassorn Potue ${ }^{1}$, \\ Siwayu Rattanakanokchai ${ }^{2}$, Sarawoot Bunbupha ${ }^{3}$, Petcharat Chiangsaen ${ }^{4}$ and Poungrat Pakdeechote ${ }^{1,5, *}$ \\ 1 Department of Physiology, Faculty of Medicine, Khon Kaen University, Khon Kaen 40002, Thailand; \\ putcma@kku.ac.th (P.M.); metee.iam@kkumail.com (M.I.); nisita@kkumail.com (N.C.); \\ anuson_p@kkumail.com (A.P.); prappo@kku.ac.th (P.P.) \\ 2 Faculty of Veterinary Medicine, Khon Kaen University, Khon Kaen 40002, Thailand; siwara@kku.ac.th \\ 3 Faculty of Medicine, Mahasarakham University, Maha Sarakham 44000, Thailand; sarawoot.b@msu.ac.th \\ 4 Faculty of Medicine, Bangkokthonburi University, Bangkok 10170, Thailand; petcharat.chi@bkkthon.ac.th \\ 5 Research Institute for Human High Performance and Health Promotion, Khon Kaen University, \\ Khon Kaen 40002, Thailand \\ check for \\ * Correspondence: ppoung@kku.ac.th; Tel.: +66-86-852-6060; Fax: +66-4334-8394
}

updates

Citation: Maneesai, P.;

Iampanichakul, M.; Chaihongsa, N.;

Poasakate, A.; Potue, P.;

Rattanakanokchai, S.; Bunbupha, S.;

Chiangsaen, P.; Pakdeechote, P.

Butterfly Pea Flower (Clitoria ternatea

Linn.) Extract Ameliorates

Cardiovascular Dysfunction and

Oxidative Stress in Nitric

Oxide-Deficient Hypertensive Rats. Antioxidants 2021, 10, 523. https:// doi.org/10.3390/antiox10040523

\section{Academic Editors:}

Stefania Pizzimenti, Giuliana Muzio and Giuseppina Barrera

Received: 25 February 2021

Accepted: 24 March 2021

Published: 27 March 2021

Publisher's Note: MDPI stays neutral with regard to jurisdictional claims in published maps and institutional affiliations.

Copyright: (c) 2021 by the authors. Licensee MDPI, Basel, Switzerland. This article is an open access article distributed under the terms and conditions of the Creative Commons Attribution (CC BY) license (https:/ / creativecommons.org/licenses/by/ $4.0 /)$.
Abstract: In this study, we examine whether Clitoria ternatea Linn. (CT) can prevent Nw-nitro-Larginine methyl ester hydrochloride (L-NAME)-induced cardiac and vascular dysfunction in rats. Male Sprague Dawley rats were given L-NAME (40 mg/kg, drinking water) and orally administered with CT extract (300 mg/ kg/day) or lisinopril ( $2.5 \mathrm{mg} / \mathrm{kg} /$ day) for 5 weeks. The main phytochemical components of the CT extract were found to be flavonoids. The CT extract alleviated the high blood pressure in rats receiving L-NAME. Decreased vasorelaxation responses to acetylcholine and enhanced contractile responses to sympathetic nerve stimulation in aortic rings and mesenteric vascular beds of L-NAME treated rats were ameliorated by CT extract supplementation. Left ventricular hypertrophy and dysfunction were developed in L-NAME rats, which were partially prevented by CT extract treatment. The CT extract alleviated upregulated endothelial nitric oxide synthase expression, decreased plasma nitrate/nitrite levels, and increased oxidative stress in LNAME rats. It suppressed high levels of serum angiotensin-converting enzyme activity, plasma angiotensin II, and cardiac angiotensin II type 1 receptor, NADPH oxidases 2, nuclear factor-kappa B, and tumor necrosis factor-alpha expression. The CT extract, therefore, partially prevented L-NAMEinduced hypertension and cardiovascular alterations in rats. These effects might be related to a reduction in the oxidative stress and renin-angiotensin system activation due to L-NAME in rats.

Keywords: Clitoria ternatea Linn.; left ventricular and vascular dysfunction; oxidative stress; reninangiotensin system; inflammation

\section{Introduction}

Since nitric oxide (NO) was discovered more than 40 years ago, it has been wellestablished as playing a crucial physiological role in blood pressure control [1]. A reduction in NO causes an impairment of endothelial function, which has been implicated in the pathogenesis of hypertension [2]. In animal models of hypertension, the blockade of NO synthesis using nitric oxide synthase inhibitors to induce cardiovascular alterations has been well-accepted $[3,4]$. Chronic inhibition of NO production by N $\omega$-nitro-L-arginine methyl ester (L-NAME) produces high blood pressure, cardiovascular hypertrophy, and dysfunction in rats. These deleterious effects of L-NAME are associated with NO depletion, renin-angiotensin system (RAS) activation, and reactive oxygen species (ROS) over-production [5,6]. Modulation of the RAS has been suggested to participate in the development of hypertension in L-NAME-treated rats, as increased angiotensin-converting 
enzyme (ACE) activity has been observed in serum [7] and tissue [8] in this animal model. Angiotensin II (Ang II) is a potent vasoconstricting peptide produced by the proteolytic cleavage of angiotensin I by ACE in endothelial cells. Ang II binds to its receptors, angiotensin II type 1 receptor $\left(\mathrm{AT}_{1} \mathrm{R}\right)$, to mediate vasoconstriction, inflammation, hypertension, and cardiac dysfunction [9].

Oxidative stress has been implicated as closely related to the pathogenesis of hypertension. Many studies have shown high levels of systemic lipid peroxidation and low levels of endogenous antioxidant enzymes in hypertensive patients and animals $[10,11]$. Additionally, there exists evidence that increased oxidative stress markers in hypertensive patients are suppressed by $\mathrm{AT}_{1} \mathrm{R}$ antagonists [12]. There is growing evidence that Ang II can induce ROS production by the activation of the $\mathrm{AT}_{1} \mathrm{R} / \mathrm{NADPH}$ oxidase signaling cascade in hypertension [13-16]. Oxidative stress is one of possible mechanisms which might contribute to L-NAME-induced hypertension in animal models. In L-NAME-treated rats, the link between RAS activation and ROS production has been evidenced. For example, high levels of plasma Ang II, the upregulation of $\mathrm{AT}_{1} \mathrm{R}$ and NADPH oxidase subunits (e.g., p47phox and gp91 ${ }^{\text {phox }}$ ) together with increases in vascular $\mathrm{O}_{2}{ }^{--}$and plasma malondialdehyde (MDA) levels, as well as a reduction in NO metabolites (NOx), have been described in L-NAME-induced hypertensive rats $[5,6,17,18]$. Subsequently, eNOS uncoupling has been demonstrated to be a major source of superoxide generations in L-NAME hypertensive rats $[19,20]$. Low levels of endogenous antioxidant enzymes, such as superoxide dismutase, catalase, and glutathione, have been noted in NO-deficient hypertensive rats [21].

Cardiac dysfunction and hypertrophy are the consequent complications of high blood pressure. These cardiac abnormalities are related to the adaptive response to pressure load and several molecular pathways. It has been reported that the activation of the nuclear factor-kappa B (NF- $\mathrm{KB}$ ) signaling pathway is required for the hypertrophic growth of cardiomyocytes [22]. NF- $\mathrm{kB}$ is an oxidative stress-sensitive transcriptional factor for inflammation, immune response, and cell growth; its activity is stimulated by several hypertrophic agonists, such as endothelin-1 and Ang II [22-24]. Additionally, the upregulation of NF- $\mathrm{kB}$ - together with the excessive expression of pro-inflammatory cytokines such as interleukin-6 (IL-6) and tumor necrosis factor-alpha (TNF- $\alpha$ ) - associated with cardiac hypertrophy has been observed in L-NAME hypertensive rats [25]. Additionally, L-NAME hypertensive rats have demonstrated changes in cardiac morphology and function [26]. Therefore, reducing RAS over-activation, oxidative stress, and inflammation might have beneficial effects for the prevention of cardiovascular alterations associated with hypertension.

Butterfly pea (or Blue-pea) is a common name of Clitoria ternatea Linn. (CT), which is a plant species in the Fabaceae family, widely distributed in Asia, Africa, and Australia. This plant has been gained more interest in recent years, as it has exhibited antioxidant, anti-inflammatory, antidiabetic, hypolipidemic, anticancer, and anti-platelet-aggregation properties [27-32]. It includes several phytochemical compounds, such as tannins, anthocyanins, flavonoid glycosides, triterpenoids, saponins, tannins, phenols, anthraquinone, and cardiac glycosides. [33,34]. A recent study has reported that the consumption of CT (as a beverage) increased plasma antioxidant capacities without hypoglycemia in healthy subjects [35]. However, little information regarding the protective effects of CT extracts on nitric oxide (NO) depletion-induced cardiovascular abnormalities has been demonstrated. The present study was designed to evaluate the preventive effects of CT extract on cardiac and vascular dysfunction in rats receiving L-NAME. We also explored the effects of CT extract on oxidative stress, the activation of the renin-angiotensin system and inflammation in L-NAME rats.

\section{Materials and Methods}

\subsection{Preparation of CT Flower Extract and Chemical Analysis of the Extract}

Dry CT flowers were obtained from the Vejpong Pharmacy (Hock An Tang) company limited (Vejpong Pharmacy, Co., Ltd., Bangkok, Thailand) and were extracted in boiling 
water for $1 \mathrm{~h}$. Thereafter, the water extract was filtered and freeze-dried to CT powder using a lyophilizer (Labconbo, Becthai Bangkok Equipment \& Chemical Co., Ltd.). The yield (calculation on the dried powder extract) was $27.78 \% \mathrm{w} / \mathrm{w}$ of the dried CT. The CT powder was packed into containers and kept at $-20^{\circ} \mathrm{C}$ until further use. To analyze the phytochemical components of the extract, reverse-phase ultra-high performance liquid chromatography coupled with quadrupole time-of-flight mass spectrometry (RP-UHPLCQTOF-MS) was applied.

\subsection{Animals and Induction of Hypertension}

Male Sprague Dawley rats weighing 220-250 g were purchased from Nomura Siam International Co, Ltd., Bangkok, Thailand. Rats were housed in an HVAC (Heating, Ventilation, and Air-Conditioning) system $\left(23 \pm 2{ }^{\circ} \mathrm{C}\right)$ with a $12 \mathrm{~h}$ dark/light cycle at the Northeast Laboratory Animal Centre. All animal procedures complied with the standards for the care and use of experimental animals and were approved by the Animal Ethics Committee of Khon Kaen University, Khon Kaen, Thailand (AEKKU-NELAC 72/2561).

The animals were randomly divided into 4 groups $(n=8 /$ each group), as follows: the control group received vehicle (drinking water, $1.5 \mathrm{~mL} / \mathrm{kg}$, p.o.), the L-NAME group received L-NAME and vehicle $(1.5 \mathrm{~mL} / \mathrm{kg}$, p.o.), and the L-NAME-treated group received L-NAME and either CT extract (300 mg/kg/day, p.o.) or lisinopril (2.5 mg/kg/day, p.o.). L-NAME (40 mg/kg/day) was dissolved in drinking water for 5 weeks in order to induce hypertension in the L-NAME group, while control rats were given tap water.

\subsection{Indirect Measurement of Blood Pressure in Conscious Rats}

Indirect blood pressure was measured weekly throughout the 5 weeks of the study using non-invasive tail cuff plethysmography (IITC/Life Science Instrument model 229 and model 179 amplifier; Woodland Hills, CA, USA). Conscious rats were placed on a restrainer and allowed to acclimate prior to blood pressure measurement. The measurement was repeated three times and expressed as mean values from each rat.

\subsection{Cardiac Function Study}

At the end of the experiment, rats were anesthetized with thiopental sodium (70 $\mathrm{mg} / \mathrm{kg}$, i.p.) and echocardiogram was performed using a Model LOGIQ S7 (GE Healthcare, WI, USA). Left ventricular (LV) structure and function were assessed from two-dimensional short-axis view and M-mode tracings were recorded for the LV internal dimension at the end-diastole (LVIDd), end-systole (LVIDs), interventricular septum at diastole (IVSd) and systole (IVSs), LV posterior wall thickness at diastole (LVPWd) and at systole (LVPWs), end diastolic volume (EDV), end systolic volume (ESV), and stroke volume (SV) from three consecutive cardiac cycles. LV fractional shortening (\% FS) was calculated by the following equation: \% LVFS = [(LVIDd - LVIDs $) /$ LVIDd $] \times 100$.

\subsection{Direct Measurement of Blood Pressure in Rats under Anaesthesia}

After cardiac function measurement, the left femoral artery was identified and cannulated using a polyethylene tube. Baseline values of systolic blood pressure (SBP), diastolic blood pressure (DBP), mean arterial pressure (MAP), and heart rate (HR) were continuously monitored for 20 min by way of a pressure transducer and recorded using the Acknowledge Data Acquisition software (Biopac Systems Inc., Santa Barbara, CA, USA).

\subsection{Vascular Function Study}

After hemodynamic assessment, the mesenteric vascular bed and the thoracic aorta were carefully isolated, then paced on a stainless-steel grid $\left(7 \times 5 \mathrm{~cm}^{2}\right)$ in a humid chamber [36]. To deplete sensory neurotransmitters and desensitize vanilloid receptors, the mesenteric beds were perfused with physiological Krebs solution containing capsaicin $(0.1 \mu \mathrm{M})$ for $20 \mathrm{~min}$, followed by $30 \mathrm{~min}$ for the washout period. The contractile responses to electrical field stimulation (EFS; at 5-40 Hz, $90 \mathrm{~V}, 1 \mathrm{~ms}$, for $30 \mathrm{~s}$ at 5-min intervals) or 
exogenous norepinephrine (NE) (0.15-15 nmol) were performed. Moreover, to determine the vasoactive performance of resistant small arteries, ACh $(0.1 \mathrm{nM}$ to $0.1 \mathrm{mM})$ or sodium nitroprusside (SNP, $0.1 \mathrm{nM}$ to $0.1 \mathrm{mM}$ ) was injected through neoprene rubber tubing proximal to the tissue under rising tone with methoxamine $(5-7 \mu \mathrm{M})$. Changes in mean perfusion pressure $(\mathrm{mmHg})$ were detected using a pressure transducer and the data were recorded using the BIOPAC System (BIOPAC Systems Inc., Santa Barbara, CA, USA). In another set of experiments, the thoracic aorta was cut into rings, mounted in $15 \mathrm{~mL}$ baths containing Krebs solution at $37{ }^{\circ} \mathrm{C}$, and gassed with a $95 \% \mathrm{O}_{2}$ and $5 \% \mathrm{CO}_{2}$ gas mixture. Isometric contractions were recorded with a resting tension of $1 \mathrm{~g}$ using a transducer connected to a 4-channel bridge amplifier, a PowerLab A/ D converter, and a PC running the Chart v5 software (PowerLab System, ADInstruments, Australia). ACh (0.001-3 $\mu \mathrm{M})$-induced endothelial-mediated relaxations and vascular response to SNP $(0.001-3 \mu \mathrm{M})$ were assessed by pre-contracting with phenylephrine $(10 \mu \mathrm{M})$; relaxation is expressed as \% relaxation.

\subsection{Assay of Oxidative Stress Markers}

Blood samples were drawn and collected into ethylenediaminetetraacetic acid (EDTA) collection tubes. The ventricular tissue was homogenized with phosphate lysis buffer and the supernatant was obtained. The levels of malondialdehyde (MDA) in plasma and ventricular supernatant were measured using thiobarbituric acid-reactive substances (TBARS), following a previously described method [6]. Briefly, $150 \mu \mathrm{L}$ of the sample was reacted with $10 \%$ TCA, $125 \mu \mathrm{L}$ of $5 \mathrm{mM}$ EDTA, $125 \mu \mathrm{L}$ of $8 \%$ SDS and $10 \mu \mathrm{L}$ of $0.5 \mu \mathrm{L} / \mathrm{mL}$ of butylated hydroxytoluene (BHT). The mixture was left for $10 \mathrm{~min}$ and then $0.6 \%$ TBA was added in an equal volume and the mixture was heated for $30 \mathrm{~min}$ in a boiling water bath. After cooling to room temperature, the mixture was centrifuged $10,000 \mathrm{~g}$ for $5 \mathrm{~min}$ at $25^{\circ} \mathrm{C}$. The absorbance of the supernatant was measured at the wavelength of $532 \mathrm{~nm}$ by spectrophotometer. A standard curve was generated using appropriate concentrations of standard 1,1,3,3-tetraethoxypropane (TEP) (0.3-10 mmol/L). Vascular superoxide $\left(\mathrm{O}_{2}{ }^{--}\right)$production in the carotid artery was determined using a chemiluminescence-based technique described previously, with some modifications [17]. In brief, the vessel was incubated with $1 \mathrm{~mL}$ oxygenated $\mathrm{Krebs}-\mathrm{KCl}$ solution at $\mathrm{pH}$ 7.4, $37^{\circ} \mathrm{C}$ for $30 \mathrm{~min}$. Thereafter, lucigenin $100 \mathrm{mM}$ was added in sample tube and place in a luminometer (Turner Biosystems, Sunnyvale, CA, USA). Luminometer count was integrated every $30 \mathrm{~s}$ for $5 \mathrm{~min}$ and averaged. Vascular tissue $\mathrm{O}_{2}^{\bullet-}$ production was expressed as relative light unit count per minute per dried weight of vascular tissues.

\subsection{Assay of Plasma Nitrate/nitrite (NOx) and TNF- $\alpha$ Level in Cardiac Tissue}

The concentrations of plasma NOx levels - the end products of nitric oxide (NO) metabolism-were determined by conversion of nitrate to nitrite using nitrate reductase and followed by Griess reagents, as previously noted [17]. The level of cardiac TNF- $\alpha$ was measured using an enzyme-immunoassay (ELISA) kit (Abcam, Cambridge, MA, USA), following the manufacturer's instructions.

\subsection{Assay of Catalase (CAT), Angiotensin-Converting Enzyme (ACE) Activity, and Angiotensin II Level}

The level of catalase (CAT) activity was measured in plasma, following a previously described method with some modifications [37]. Briefly, $20 \mu \mathrm{L}$ of plasma sample was added to a 96-well plate. Then, the sample was mixed with $100 \mu \mathrm{L}$ of substrate $(65 \mu \mathrm{mol} / \mathrm{mL}$ hydrogen peroxide; $\left.\mathrm{H}_{2} \mathrm{O}_{2}\right)$ in $0.06 \mathrm{M}$ sodium-potassium phosphate $\left(\mathrm{HKNaO}_{4} \mathrm{P}\right)$ buffer $(\mathrm{pH}$ 7.4 , at $37^{\circ} \mathrm{C}$ for $1 \mathrm{~min}$ ). The enzymatic reaction was stopped by adding $100 \mu \mathrm{L}$ of $32.4 \mathrm{mM}$ ammonium molybdate $\mathrm{NH}_{46}\left(\mathrm{Mo}_{7} \mathrm{O}_{24} \cdot 4 \mathrm{H}_{2} \mathrm{O}\right)$. The yellow complex was determined under a $405 \mathrm{~nm}$ wavelength. A standard curve was generated with concentrations of bovine liver catalase from 3.125 to $100 \mathrm{U} / \mathrm{mL}$. The value of serum CAT activity is expressed as $\mathrm{U} / \mathrm{mL}$.

Serum ACE activity was determined using a fluorescence assay, as previously described, with some modifications [38]. The serum was mixed with hippuryl-1-histidyl-1leucine (HHL) in assay buffer, then incubated at $37^{\circ} \mathrm{C}$ for $30 \mathrm{~min}$. After that, $\mathrm{NaOH}$ was 
added to stop the reaction and the product of the reaction was fluorogenically labelled with O-phthaldialdehyde (OPA). The fluorescence was read at $355 \mathrm{~nm}$ excitation, $535 \mathrm{~nm}$ emission using a fluorescent plate reader. Plasma Ang II level was measured using an Angiotensin II EIA Kit (RAB0010; Sigma-Aldrich), as per the standard procedures mentioned in the kit.

\subsection{Western Blot Analysis of eNOS and $A T_{1}$ Receptor $\left(A T_{1} R\right)$ and NF- $\kappa B$ Protein Expression}

The levels of eNOS, $\mathrm{AT}_{1} \mathrm{R}$, and NF- $\mathrm{kB}$ protein expression in $\mathrm{LV}$ tissue were determined using the Western blot method. A mouse monoclonal antibody to eNOS (Cat. 610296, BD Bioscience, San Jose, CA, USA), rabbit polyclonal antibody to $\mathrm{AT}_{1} \mathrm{R}$ (N-10) (sc-1173, Santa Cruz Biotechnology, Inc., Santa Cruz, CA, USA), rabbit polyclonal immunoglobulin G (IgG) to p-NF-kB p65 (S536, Cell Signaling Technology, Inc., Danvers, MA, USA), and mouse monoclonal IgG to gp91 $1^{\text {phox }}$ (sc-74514, Santa Cruz Biotechnology, Inc., Santa Cruz, CA, USA) were used in the current study. $\beta$-actin was used as a protein loading control in order to compare the intensities of protein expression.

\subsection{Statistical Analysis}

The results of this study are expressed as mean \pm SEM. Statistical analysis was carried out using one-way ANOVA follow by Tukey's post hoc tests for comparison between groups. A probability value less than 0.05 was considered statistically significant.

\section{Results}

\subsection{The Main Phytochemical Components in CT Extract}

A total of 2110 compounds were detected in the positive electrospray ionization mode and 282 compounds were found in the negative electrospray ionization mode. Background signals were removed when the coefficient of variation was less than $30 \%$. Thereafter, metabolite identification was performed. The main compounds in the aqueous extracts of CT were flavonoids, such as kaempferol 3-glucoside, quercetin 3-rhamnosyl-rhamnosylglucoside, rutin, quercetin 3-glucoside, and kaempferol 3-isorhamninoside (see Table 1). In addition, L-tryptophan, an amino acid, was also found in the CT extract.

Table 1. Main compounds in CT extract, as assayed by reverse-phase ultra-high performance liquid chromatography coupled with quadru-pole time-of-flight mass spectrometry.

\begin{tabular}{ccccc}
\hline RT & {$[\mathbf{M}+\mathbf{H}]^{+}(\mathbf{m} / \mathbf{z})$} & Identified Compounds & Formula & Class of Phytochemicals \\
\hline 7.38 & 449.11 & Kaempferol 3-glucoside & $\mathrm{C}_{21} \mathrm{H}_{20} \mathrm{O}_{11}$ & Flavonoids \\
6.84 & 757.22 & Quercetin 3-rhamnosyl-rhamnosyl-glucoside & $\mathrm{C}_{33} \mathrm{H}_{40} \mathrm{O}_{20}$ & Flavonoids \\
7.28 & 611.16 & Rutin & $\mathrm{C}_{27} \mathrm{H}_{30} \mathrm{O}_{16}$ & Flavonoids \\
7.46 & 465.10 & Quercetin 3-glucoside & $\mathrm{C}_{21} \mathrm{H}_{20} \mathrm{O}_{12}$ & Flavonoids \\
7.39 & 741.22 & Kaempferol 3-isorhamninoside & $\mathrm{C}_{33} \mathrm{H}_{40} \mathrm{O}_{19}$ & Flavonoids \\
\hline
\end{tabular}

$\mathrm{RT}$, retention time; $\mathrm{m} / \mathrm{z}$, mass-to-charge ratio; $\mathrm{CT}$, Clitoria ternatea Linn.

\subsection{CT Extract Exhibited an Antihypertensive Effect in L-NAME Hypertensive Rats}

During the five weeks of L-NAME treatment, SBP progressively increased compared with the control group $(191 \pm 2.98$ vs. $114.65 \pm 1.48 \mathrm{mmHg} ; p<0.05$; Figure 1$)$. Daily oral administration of CT extract or lisinopril significantly prevented the development of hypertension induced by L-NAME (129.21 \pm 1.33 and $118.5 \pm 0.80 \mathrm{mmHg}$, respectively) when compared with untreated hypertensive rats $(p<0.05)$. The dose $(300 \mathrm{mg} / \mathrm{kg} /$ day $)$ of $\mathrm{CT}$ extract used in the present study was based on the result from a preliminary study. CT extract at doses of 100 and $300 \mathrm{mg} / \mathrm{kg} /$ day produced dose-dependent anti-hypertensive effects; however, there was no significant difference between 300 and $500 \mathrm{mg} / \mathrm{kg} /$ day doses $(n=4)$. 


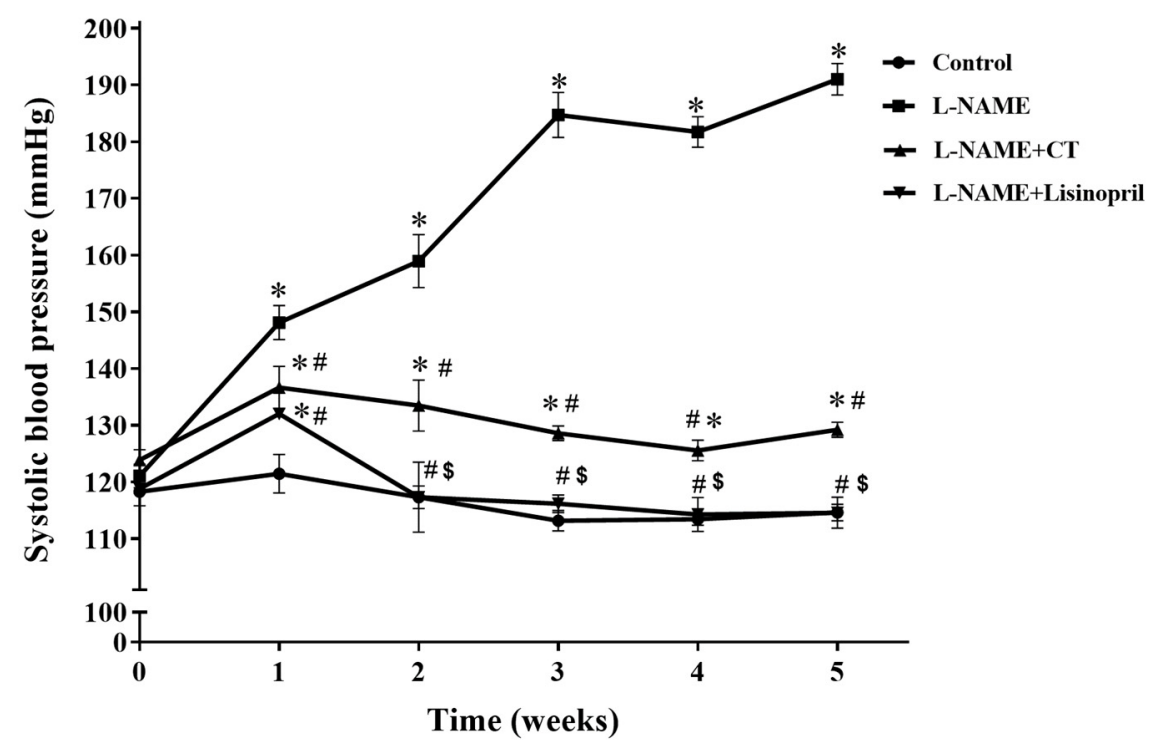

Figure 1. Effects of CT extract and lisinopril on systolic blood pressure in conscious rats. Data are expressed as mean $\pm \operatorname{SEM}\left(n=8\right.$ /group), ${ }^{*} p<0.05$ vs. control, ${ }^{\#} p<0.05$ vs. L-NAME, ${ }^{\$} p<0.05$ vs. L-NAME + CT. CT:; Clitoria ternatea Linn. extract.

The SBP, DBP, MAP, and HR in anesthetized rats of all groups in the experiment are shown in Table 2. Significant increases in all hemodynamic parameters were observed in L-NAME hypertensive rats compared to the control rats $(p<0.05)$. Treatment with CT extract significantly prevented all hemodynamic alterations caused by L-NAME $(p<0.05)$. Moreover, lisinopril treatment also abolished the hypertension induced by L-NAME, as there were no significant differences of SBP, DBP, MAP, and HR in L-NAME treated with lisinopril and control rats $(p<0.05$; Table 2$)$.

Table 2. Effects of CT extract and lisinopril on blood pressure, heart rate, heart weight per body weight, and left ventricular weight per body weight.

\begin{tabular}{ccccc}
\hline Parameters & Control & L-NAME & L-NAME + CT (300 mg/kg) & L-NAME + Lisinopril (2.5 mg/kg) \\
\hline SBP (mmHg) & $117.63 \pm 5.11$ & $187.39 \pm 4.56^{*}$ & $130.95 \pm 2.82^{* *}$ & $131.18 \pm 4.59 * \#$ \\
DBP (mmHg) & $72.64 \pm 6.01$ & $133.29 \pm 4.65^{*}$ & $86.07 \pm 2.31^{*} \#$ & $96.31 \pm 4.43^{* \#}$ \\
MAP (mmHg) & $87.64 \pm 5.37$ & $151.32 \pm 4.55^{*}$ & $101.03 \pm 2.94^{* \#}$ & $109.55 \pm 4.67 * \#$ \\
HR (beat/min) & $331.74 \pm 24.13$ & $383.08 \pm 12.56^{*}$ & $332.02 \pm 6.55^{\#}$ & $333.33 \pm 15.65^{\#}$ \\
HW/BW (g) & $0.264 \pm 0.006$ & $0.272 \pm 0.005^{*}$ & $0.270 \pm 0.006^{\#}$ & $0.271 \pm 0.005^{\#}$ \\
LV/BW (g) & $0.171 \pm 0.002$ & $0.187 \pm 0.004^{*}$ & $0.169 \pm 0.003^{\#}$ & $0.174 \pm 0.002^{\#}$ \\
\hline
\end{tabular}

Data are expressed as mean \pm SEM. $n=8$ /group, ${ }^{*} p<0.05$ vs. control, $\# p<0.05$ vs. L-NAME. SBP: systolic blood pressure, DBP: diastolic blood pressure, MAP: mean arterial pressure, HR: heart rate, HW/BW: heart weight per body weight, LV/BW: left ventricular weight per body weight, CT: Clitoria ternatea Linn. extract.

In addition, heart weight per body weight (HW/BW) and left ventricular weight per body weight $(\mathrm{LV} / \mathrm{BW})$ in L-NAME hypertensive rats were significantly increased compared to the control rats $(p<0.05)$. CT extract supplementation significantly reduced $\mathrm{HW} / \mathrm{BW}$ and $\mathrm{LV} / \mathrm{BW}$, as shown in Table 2. Similar results were observed with lisinopril supplementation $(p<0.05)$.

\subsection{CT Extract Alleviated Vascular Dysfunction in L-NAME Hypertensive Rats}

After five weeks of treatment, vasorelaxation responses to ACh $(0.001-3 \mu \mathrm{M})$ were significantly impaired in aortic rings of L-NAME-induced hypertensive rats compared to the response in control rats (at $3 \mu \mathrm{M}$ ACh: $14.25 \pm 2$ vs. $75.48 \pm 4.67 \%, p<0.05$ ). Treatment with CT extract or lisinopril significantly improved vasorelaxation responses to $\mathrm{ACh}$ (at $3 \mu \mathrm{M}$ ACh: $45.96 \pm 5.97$ and $40.34 \pm 3.95 \%$, respectively) compared to L-NAME-induced 
hypertensive rats $(p<0.05$; Figure 2A). However, vasorelaxation responses to SNP, an NO donor $(0.001-3 \mu \mathrm{M})$, did not significantly differ among groups $(p>0.05$; Figure $2 B)$.

A

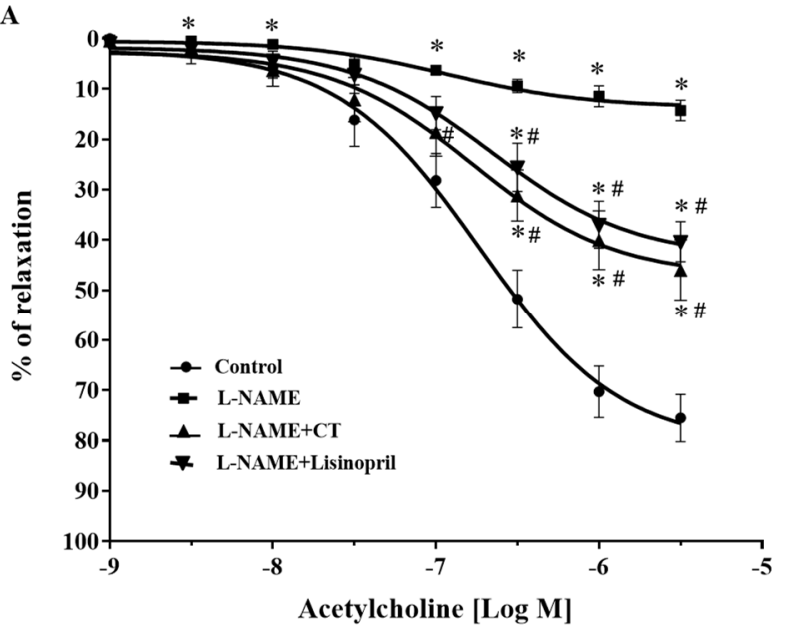

C

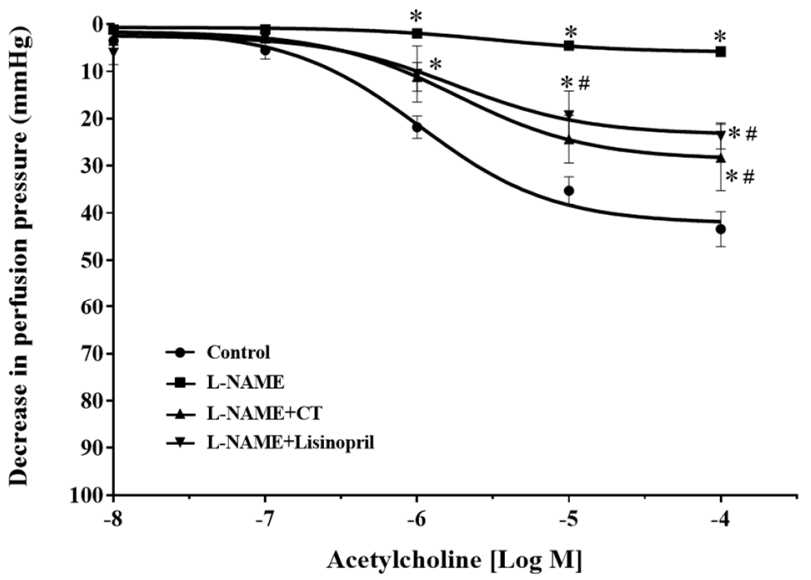

B

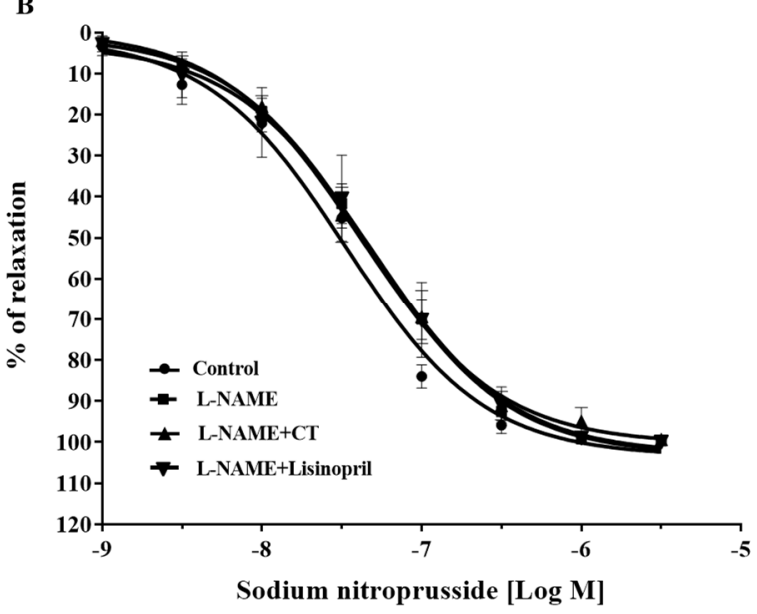

$\mathbf{D}$

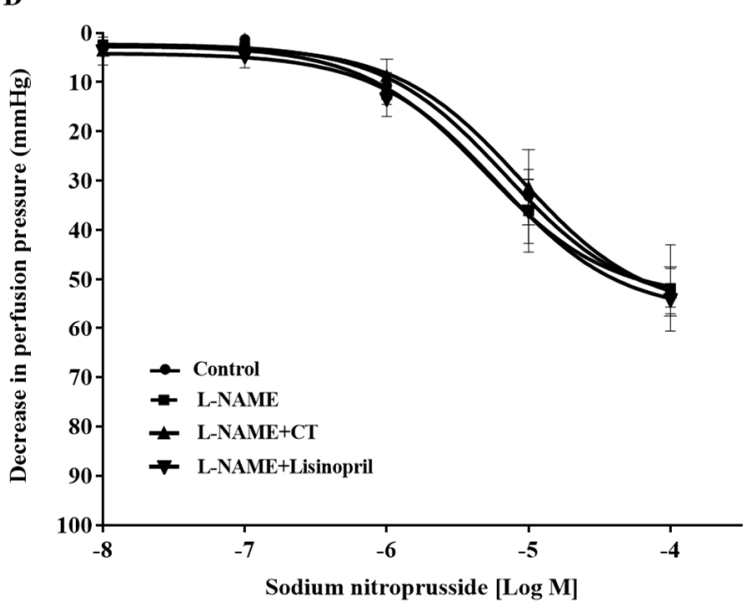

Figure 2. Effects of CT extract and lisinopril on vascular function in thoracic aorta $(\mathbf{A}, \mathbf{B})$ and mesenteric vascular beds $(\mathbf{C}, \mathbf{D})$ in all groups of the experiment. Data are expressed as mean $\pm \operatorname{SEM}(n=8 /$ group $),{ }^{*} p<0.05$ vs. control, ${ }^{\#} p<0.05$ vs. L-NAME, CT: Clitoria ternatea Linn. extract.

In addition, an impairment of endothelial function was confirmed in the mesenteric vascular bed, as significant reductions in vasorelaxation responses to $\mathrm{ACh}(0.1 \mathrm{nM}$ to $0.1 \mathrm{mM})$ were observed in the mesenteric vascular beds isolated from L-NAME-induced hypertensive rats compared to the responses in control rats (at $0.1 \mathrm{mM}$ ACh: $9.58 \pm 3.9$ vs. $37.42 \pm 4.71$ $\mathrm{mmHg}, p<0.05)$. The response was significantly improved in rats treated with CT extract or lisinopril (at $0.1 \mathrm{mM}$ ACh: $24.52 \pm 6.96$ and $23.65 \pm 2.72 \mathrm{mmHg}$, respectively) compared to the L-NAME hypertensive rats $(p<0.05$; Figure $2 \mathrm{C})$. However, the vasorelaxation response to SNP $(0.1 \mathrm{nM}$ to $0.1 \mathrm{mM})$ did not significantly differ among groups $(p>0.05)$, which indicated normal vascular smooth muscle cell function (Figure 2D).

\subsection{CT Extract Attenuated Contractile Responses to Electrical Filed Stimulation (EFS) in Mesenteric Vascular Beds Isolated from L-NAME Hypertensive Rats}

Frequency-dependent contractile responses to EFS (at 5-40 Hz) were observed in all groups of rats, as shown in Figure 3A. Interestingly, significant enhancements of contractile responses to EFS were observed in the mesenteric vascular beds isolated from L-NAME rats compared to the responses in the control rats (at $40 \mathrm{~Hz}: 68.09 \pm 5.60$ vs. $30.26 \pm 4.67$ $\mathrm{mmHg}, p<0.05$ ). CT extract or lisinopril treatment attenuated these responses to EFS (33.77 \pm 5.79 and $36.38 \pm 3.52 \mathrm{mmHg}$, respectively) compared to the response in untreated rats 
$(p<0.05$; Figure 3A). However, the contractile response to exogenous NE $(0.15-15 \mathrm{nmol})$ did not show a significant difference among groups ( $p>0.05$; Figure $3 \mathrm{~B})$.

A

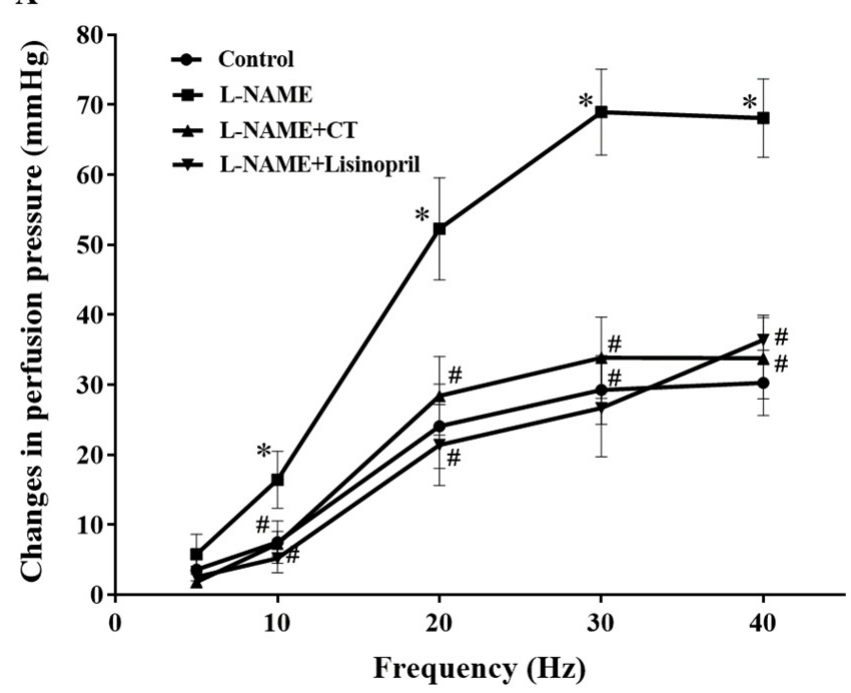

B

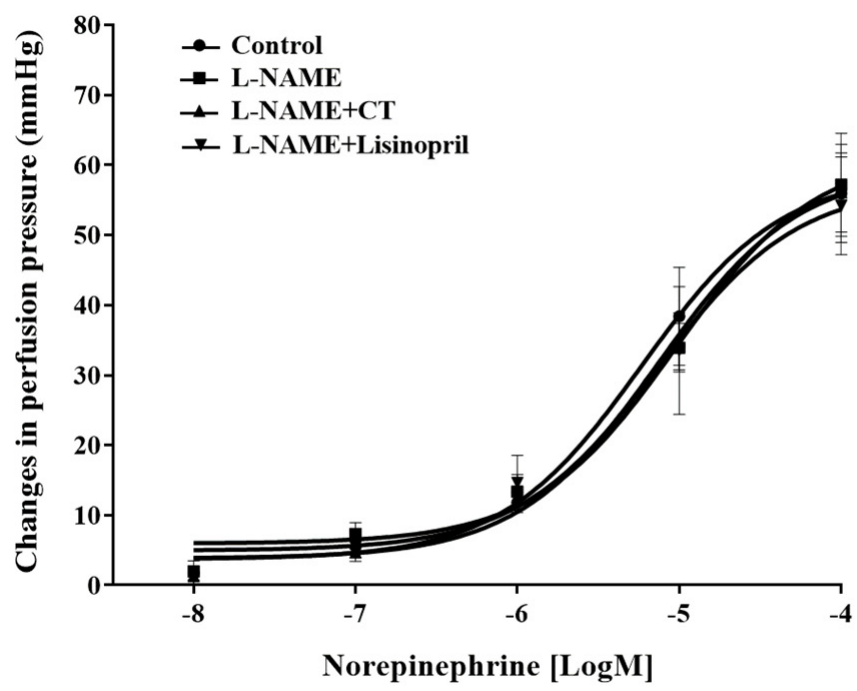

Figure 3. Effects of CT extract and lisinopril on contractile responses to electrical field stimulation (A) and exogenous norepinephrine (B) in mesenteric vascular beds collected from all groups in the experiment. Data are expressed as mean \pm $\operatorname{SEM}\left(n=8 /\right.$ group), ${ }^{*} p<0.05$ vs. control, ${ }^{*} p<0.05$ vs. L-NAME. CT: Clitoria ternatea Linn. extract.

\subsection{CT Extract Prevented Cardiac Dysfunction Induced by L-NAME in Rats}

An impairment of LV function was observed in L-NAME hypertensive rats, which was characterized by increases in IVSd and LVPWd and decreases in LVIDd, EDV, \%EF, $\mathrm{SV}$, and \%FS compared with those of control rats $(p<0.05$, Table 3$)$. L-NAME rats treated with CT extract showed an improvement in LV function, supported by restorations of IVSd, $\%$ EF, SV, \%FS, IVSd, and LVPWd compared with untreated rats $(p<0.05$, Figure 4$)$. In addition, lisinopril significantly reduced IVSd and LVPWd, accompanied with significant improvements in \%EF, SV, and \%FS compared with untreated L-NAME rats $(p<0.05$; Table 3).

Table 3. Effects of CT extract and lisinopril on ventricular dysfunction in all groups of the experiment.

\begin{tabular}{ccccc}
\hline Parameters & Control & L-NAME & L-NAME + CT (300 $\mathbf{~ m g / k g )}$ & L-NAME + Lisinopril (5 mg/kg) \\
\hline IVSd (mm) & $1.77 \pm 0.03$ & $2.59 \pm 0.30^{*}$ & $1.65 \pm 0.08^{\#}$ & $1.63 \pm 0.11^{\#}$ \\
IVSs (mm) & $2.68 \pm 0.12$ & $3.26 \pm 0.43$ & $2.74 \pm 0.17$ & $2.65 \pm 0.14$ \\
LVIDd (mm) & $6.62 \pm 0.27$ & $4.91 \pm 0.36^{*}$ & $6.60 \pm 0.37^{\#}$ & $5.70 \pm 0.44$ \\
LVIDs (mm) & $3.71 \pm 0.17$ & $3.41 \pm 0.34$ & $4.00 \pm 0.28$ & $3.32 \pm 0.28$ \\
LVPWd (mm) & $2.08 \pm 0.07$ & $2.81 \pm 0.22^{*}$ & $1.94 \pm 0.06^{\#}$ & $2.19 \pm 0.19^{\#}$ \\
LVPWs (mm) & $2.78 \pm 0.12$ & $3.14 \pm 0.27$ & $2.80 \pm 0.08$ & $2.70 \pm 0.36$ \\
EDV (mL) & $0.68 \pm 0.08$ & $0.30 \pm 0.07^{*}$ & $0.67 \pm 0.09^{\#}$ & $0.55 \pm 0.06$ \\
ESV (mL) & $0.14 \pm 0.02$ & $0.12 \pm 0.04$ & $0.17 \pm 0.03$ & $0.15 \pm 0.02$ \\
EF (\%) & $79.27 \pm 2.86$ & $66.33 \pm 4.51^{*}$ & $76.39 \pm 1.40^{\#}$ & $78.66 \pm 2.16^{\#}$ \\
SV (mL) & $0.55 \pm 0.08$ & $0.19 \pm 0.04^{*}$ & $0.50 \pm 0.06^{\#}$ & $0.43 \pm 0.04^{\#}$ \\
FS (\%) & $43.78 \pm 2.78$ & $30.95 \pm 3.22^{*}$ & $40.90 \pm 1.08^{\#}$ & $42.08 \pm 2.10^{\#}$ \\
\hline
\end{tabular}

Data are expressed as means \pm SEM. $\left(n=5-8 /\right.$ group). ${ }^{*} p<0.05$ vs. control, ${ }^{\#} p<0.05$ vs. L-NAME. IVSd: interventricular septum thickness at end diastole, IVSs: interventricular septum thickness at end systole, LVIDd: left ventricular internal dimension at end-diastole, LVIDs: left ventricular internal dimension at end-systole, LVPWd: left ventricular posterior wall thickness in diastole, LVPWs: left ventricular posterior wall thickness in systole, EDV: end-diastolic volume, ESV: end systolic volume, EF: ejection fraction, SV: stroke volume, FS: fractional shortening, CT: Clitoria ternatea Linn. extract. 


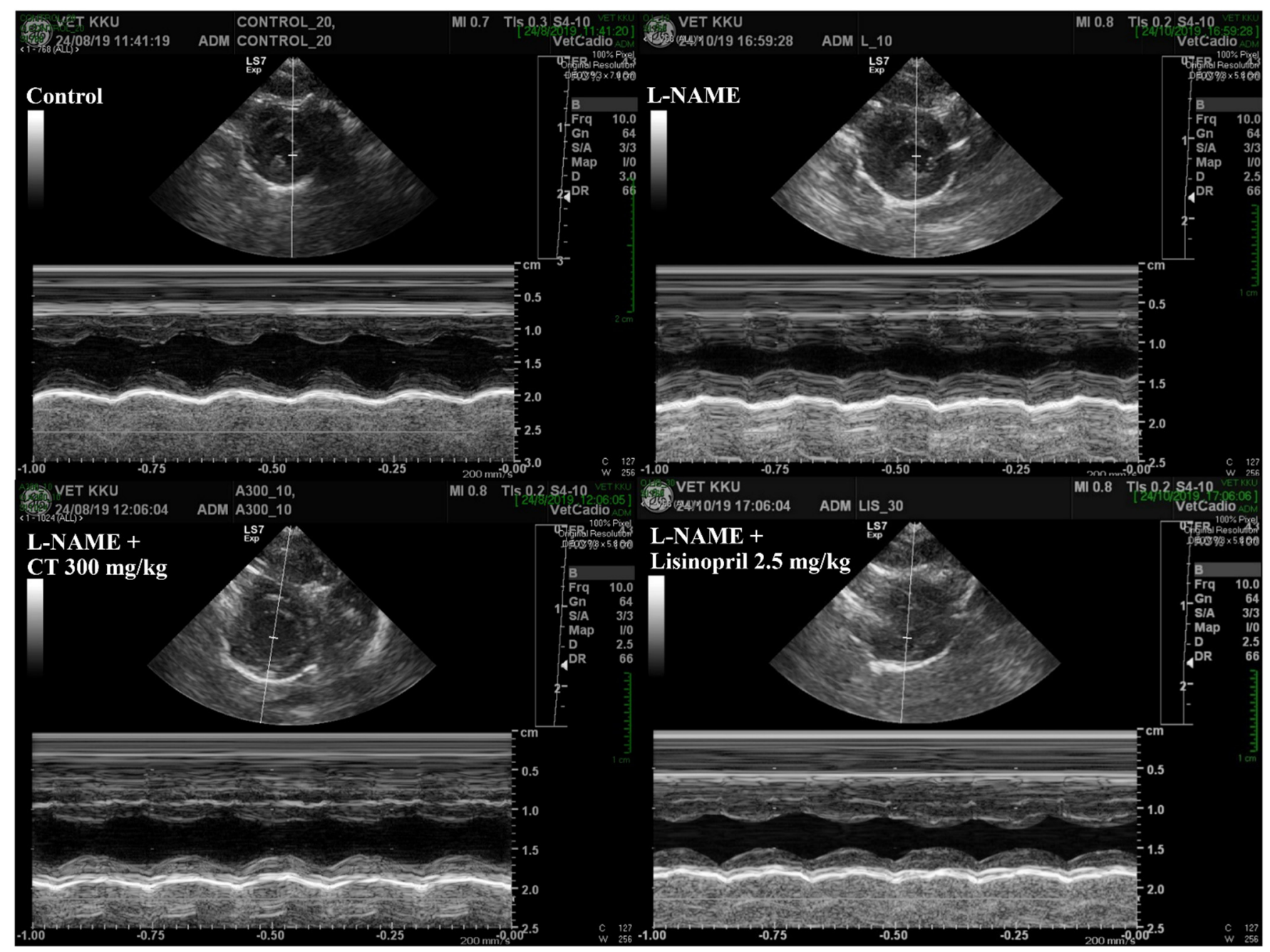

Figure 4. Representative tracings of transthoracic echocardiographs in all groups of rats. CT: Clitoria ternatea Linn. extract.

3.6. CT Extract Improved Plasma Nitric Oxide Metabolites (NOx) and Cardiac eNOS Protein Expression in L-NAME Hypertensive Rats

In L-NAME treated rats, a significant decrease in plasma NOx concentration was found compared to the control rats $(2.61 \pm 0.12$ vs. $11.78 \pm 1.19 \mu \mathrm{M}, p<0.05)$. This low level of NOx was restored by CT extract and lisinopril supplementation (7.33 \pm 0.48 and $6.02 \pm 0.21 \mu \mathrm{M}$, respectively; $p<0.05$; Figure 5A). The NOx level was in accordance with a downregulation of eNOS protein expression in cardiac tissue in L-NAME hypertensive rats compared to the control (Figure 5B). However, treatment with CT extract or lisinopril significantly upregulated eNOS protein expression in L-NAME hypertensive rats compared to untreated rats $(p<0.05$; Figure $5 \mathrm{~B})$.

\subsection{CT Extract Reduced Oxidative Stress in L-NAME Hypertensive Rats}

A high level of vascular $\mathrm{O}_{2}^{\bullet-}$ production (151.94 \pm 7.14 vs. $57.97 \pm 3.55$ count $/ \mathrm{mg}$ dry $\mathrm{wt} / \mathrm{min} ; p<0.05)$ and a low level of plasma catalase activity (36.77 $\pm 4.20 \mathrm{vs} .103 .52 \pm 17.13$ $\mathrm{U} / \mathrm{mL}$; Figure 6A,B) were observed in L-NAME hypertensive rats compared to control rats. $\mathrm{CT}$ extract or lisinopril treatment alleviated the production of vascular $\mathrm{O}_{2}^{\bullet-}(90.04 \pm 3.25$ and $84.72 \pm 8.72 \mathrm{count} / \mathrm{mg}$ dry $\mathrm{wt} / \mathrm{min}$, respectively) and restored serum CAT activity back to the normal level (107.9 \pm 19.72 and $106.78 \pm 15.42 \mathrm{U} / \mathrm{mL}$, respectively), as shown in Figure 6A and B. Moreover, levels of plasma and cardiac MDA were higher in L-NAME rats than those in control rats $(16.48 \pm 0.86$ vs. $7.08 \pm 0.68 \mu \mathrm{M}$ and $3.39 \pm 0.43$ vs. $1.58 \pm$ $0.21 \mu \mathrm{M} / \mathrm{g}$ tissue, $p<0.05)$. Supplementation with CT extract and lisinopril restored the 
level of plasma $(9.51 \pm 0.73$ and $10.30 \pm 0.67 \mu \mathrm{M})$ and cardiac MDA $(1.58 \pm 0.13$ and 1.88 $\pm 0.12 \mu \mathrm{M} / \mathrm{g}$ tissue) in hypertensive rats compared to the untreated group (Figure 6C,D).

A

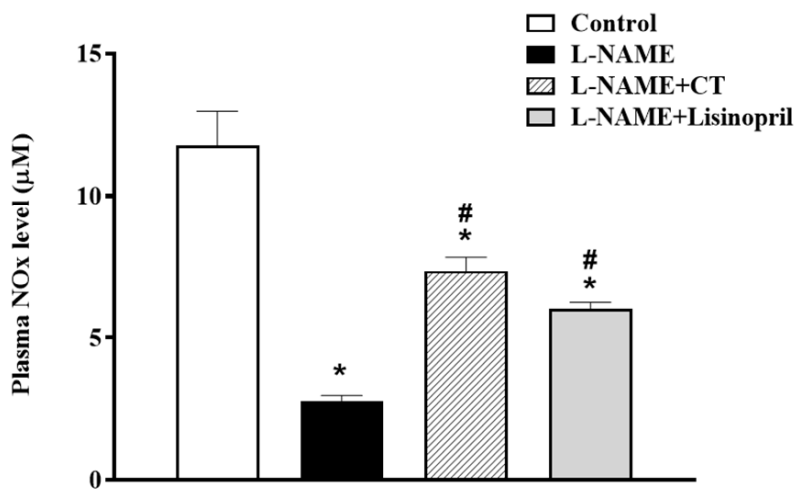

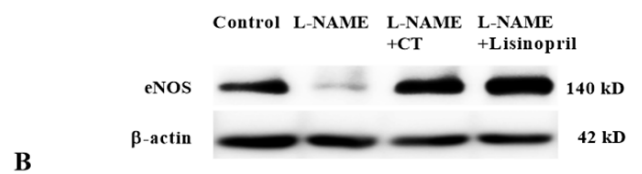

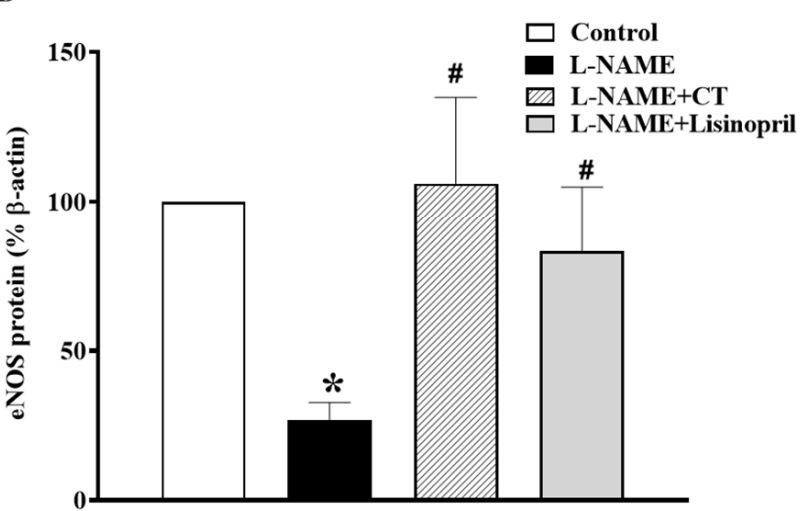

Figure 5. Effects of CT extract and lisinopril on nitric oxide metabolites (A) and endothelial nitric oxide synthase (eNOS) protein expressions (B) in cardiac tissue of all groups in the experiment. Data are expressed as mean \pm SEM ( $n=4 /$ group), ${ }^{*} p<0.05$ vs. control, ${ }^{\#} p<0.05$ vs. L-NAME, CT: Clitoria ternatea Linn. extract.
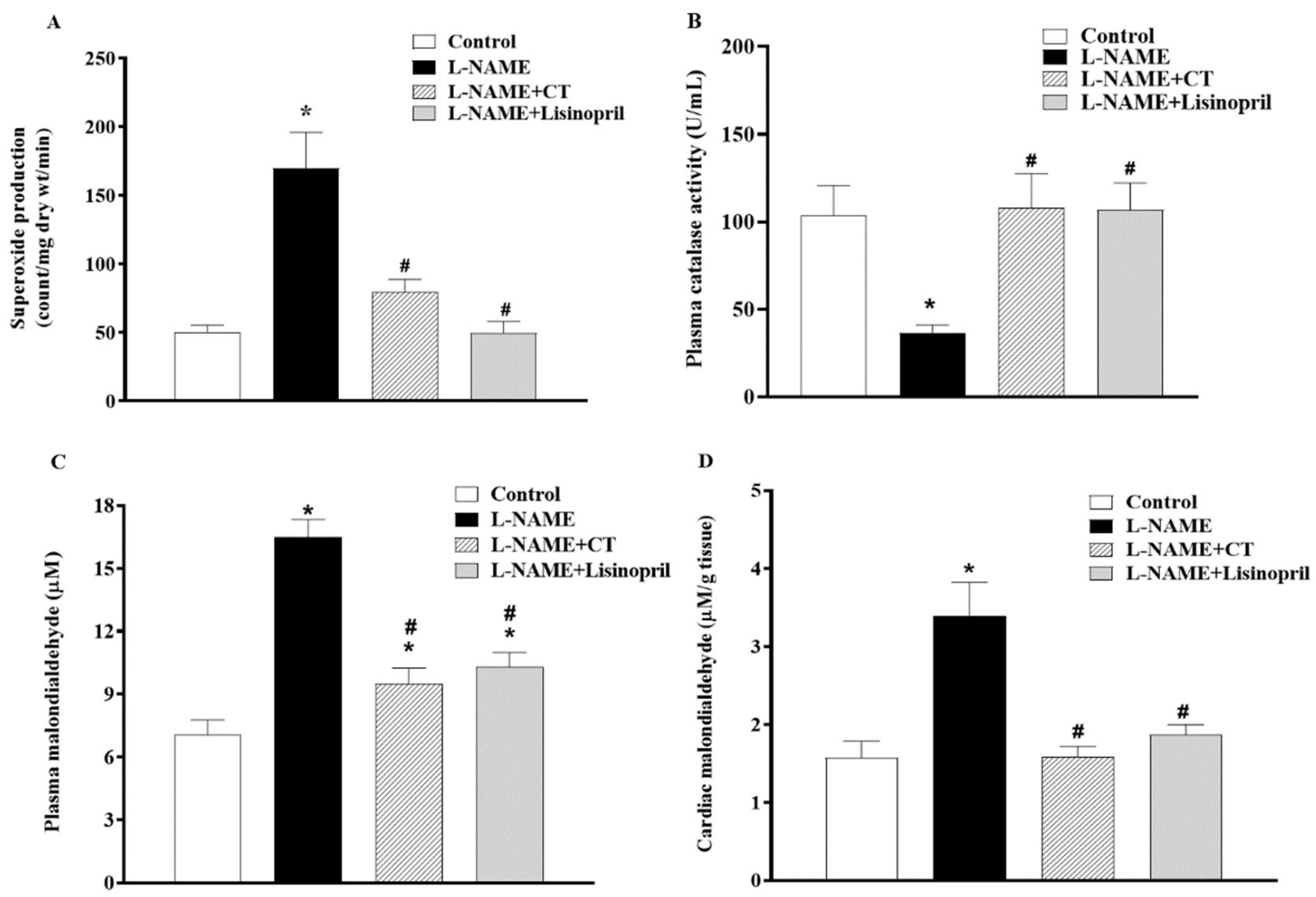

Figure 6. Effects of CT extract and lisinopril on vascular superoxide production (A), plasma catalase activity (B), plasma malondialdehyde (MDA) (C), and cardiac MDA levels (D) in all groups in the experiment. Data are expressed as mean \pm SEM ( $n=8$ /group), ${ }^{*} p<0.05$ vs. control, ${ }^{\#} p<0.05$ vs. L-NAME; L: L-NAME, CT: Clitoria ternatea Linn. extract. 
3.8. CT Extract Suppressed Serum Angiotensin-Converting Enzyme (ACE) Activity, Plasma Angiotensin II (Ang II) Level, Angiotensin II Receptor Type 1 (AT 1 R), NOX2, and p-NF- $\kappa B$ Protein Expressions in Cardiac Tissue Collected from L-NAME Hypertensive Rats

There were significant increases in serum ACE activity and plasma Ang II levels in L-NAME-induced hypertensive rats compared to control rats $(174.64 \pm 25.07$ vs. $65.47 \pm$ $9.40 \mathrm{mU} / \mathrm{mL}$ and $16.22 \pm 1.01$ vs. $5.85 \pm 2.20 \mathrm{pg} / \mathrm{mL}$, respectively; $p<0.05)$. CT extract or lisinopril significantly reduced serum ACE activity $(95.27 \pm 5.78$ and $67.61 \pm 14.61 \mathrm{mU} / \mathrm{mL}$, respectively) and plasma Ang II levels (9.50 \pm 0.87 and $10.41 \pm 0.79 \mathrm{pg} / \mathrm{mL}$, respectively) compared to untreated L-NAME hypertensive rats $(p<0.05$;Figure $7 \mathrm{~A}, \mathrm{~B})$. Interestingly, the overexpression of $\mathrm{AT}_{1} \mathrm{R}$ and NOX2 protein expressions in $\mathrm{LV}$ was observed in the L-NAME hypertensive group compared to the control group $(p<0.05$;Figure $7 \mathrm{C}, \mathrm{D})$. CT extract and lisinopril attenuated the overexpression of these proteins, as shown in Figure 7C,D. High levels of TNF- $\alpha$ were found in hypertensive rats, which was relevant to the overexpression of $\mathrm{p}-\mathrm{NF}-\mathrm{\kappa B}$ protein compared to the control group $(p<0.05)$. However, $\mathrm{CT}$ extract and lisinopril treatment restored these high levels of TNF- $\alpha$ and p-NF- $\kappa B$ protein expression, as shown in Figure 7E,F.
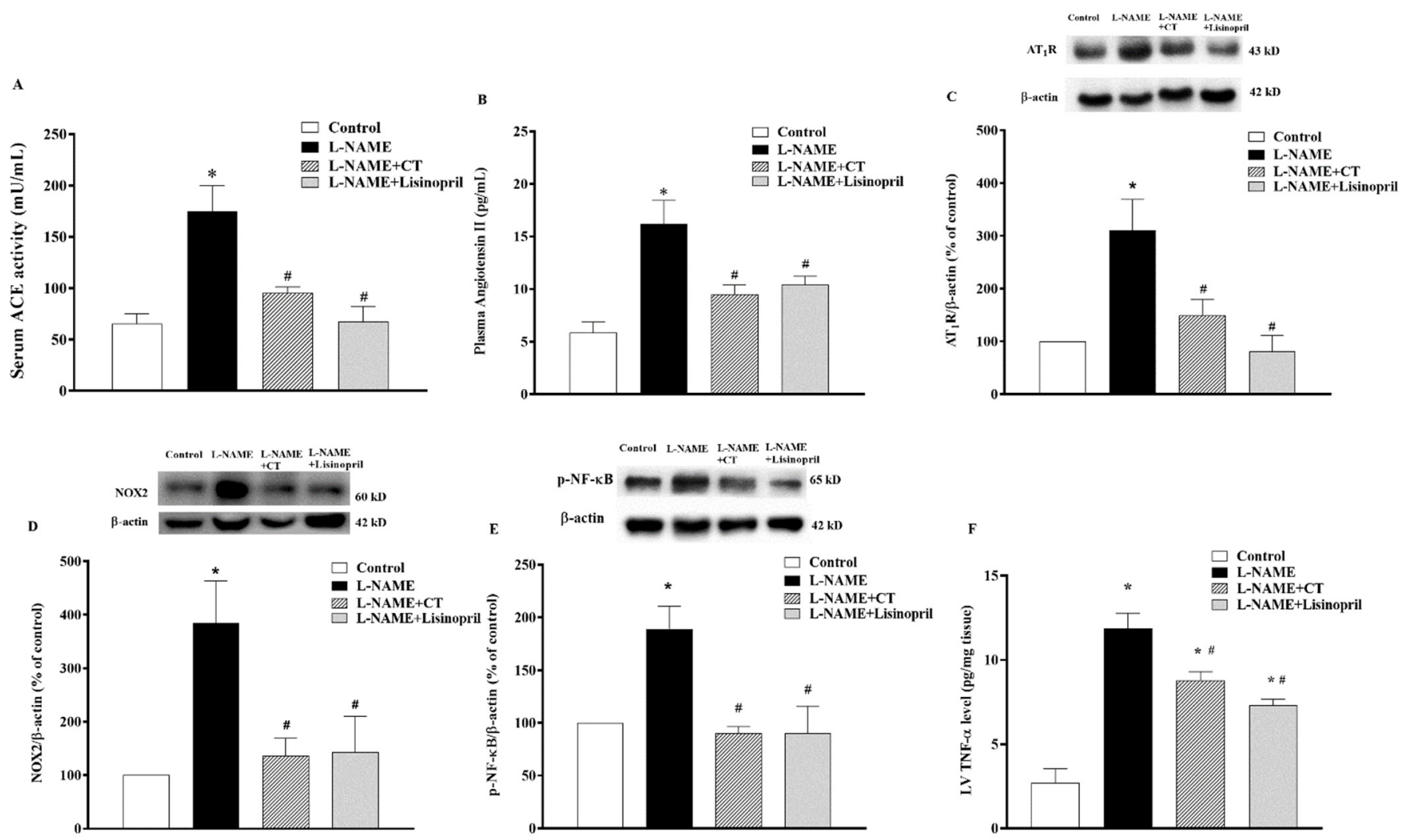

Figure 7. Effects of CT extract and lisinopril on serum angiotensin-converting enzyme activity (ACE, (A)), plasma angiotensin II level (Ang II, (B)), angiotensin II receptor type $1\left(\mathrm{AT}_{1} \mathrm{R}\right)(\mathbf{C}), \mathrm{NOX} 2(\mathbf{D}), \mathrm{p}-\mathrm{NF}-\mathrm{kB}$ protein expressions (E), and tumor necrosis factor-alpha (TNF- $\alpha$ ) level in cardiac tissue $(\mathbf{F})$ of all groups in the experiment. ${ }^{*} p<0.05$ vs. control, ${ }^{\#} p<0.05$ vs. L-NAME, CT: Clitoria ternatea Linn. extract.

\section{Discussion}

We found that the main phytochemical components of CT extract are flavonoids. CT extract prevented hypertension induced by NO depletion in rats. The impairment of left ventricular and vascular function in rats receiving L-NAME was protected by treatment with CT extract. Likewise, it increased eNOS protein expression and plasma NOx in L-NAME rats. Oxidative stress, as evidenced by increases in superoxide generation and plasma lipid peroxidation, as well as a reduction in plasma CAT activity in hypertensive rats, was alleviated by CT extract treatment. RAS activation, inflammation, and upregula- 
tion of $\mathrm{AT}_{1} \mathrm{R}, \mathrm{NOX} 2$, and $\mathrm{p}-\mathrm{NF}-\mathrm{kB}$ in cardiac tissue were observed in L-NAME rats, but were suppressed under $\mathrm{CT}$ extract supplementation.

Several lines of evidence have reported that L-NAME-induced hypertension is related to reduce NO bioavailability, resulting in endothelial dysfunction and hypertension [39,40]. This study demonstrated that hypertensive rats had a reduction in vasorelaxant responses to ACh without changes in their response to a NO donor. An enhancement in contractile responses to nerve stimulation was observed in L-NAME rats, while the response to exogenous NE was not altered. These findings were supported by the downregulation of eNOS and low levels of plasma NOx in L-NAME rats. The reduction in eNOS protein expression in the present study was consistent with previous studies [18,41,42]; however, Pechanova and co-workers found increases in eNOS expression and activity in rats treated with L-NAME [43]. The controversy of eNOS expression induced by L-NAME in rats might be caused by different strains of rats, treatment periods and doses of L-NAME, etc. There is evidence to support that $\mathrm{NO}$ can modulate sympathetic nerve-mediated contractile responses by deactivating the vasoconstrictor norepinephrine [44]. Moreover, L-NAME treatment can produce ROS by oxidizing tetrahydrobiopterin (the cofactor of NO synthesis), leading to the uncoupling of the NOS dimer. Uncoupled NOS causes a reduction in NOS activity, contributing to producing the $\mathrm{O}_{2}{ }^{\bullet-}$ radical, rather than $\mathrm{NO}$ [45]. This was consistent with our results, in which L-NAME-treated rats showed an increase in oxidative stress determined by increased vascular $\mathrm{O}_{2}{ }^{\bullet-}$ production, plasma and cardiac MDA levels, and low plasma catalase activity. Another possible mechanism of decreased NO bioavailability in L-NAME rats is that superoxide can rapidly react with NO to form peroxynitrite, a strong oxidant [46]. In this study, only catalase was measured based on the previous reports that the decrease in the steady state of superoxide dismutase (SOD) and catalase was not different in response to oxidative stress conditions [47,48]. Similar reactivities to singlet oxygen for both enzymes were confirmed [49]. Additionally, catalase can be reduced dramatically in the presence of superoxide radicals [50]. Therefore, the measurement of catalase, an intracellular antioxidant enzyme, might imply oxidative stress in this animal model. L-NAME rats receiving CT extract had lower blood pressure than untreated rats. Additionally, vascular dysfunction in L-NAME rats was resolved by CT extract supplementation. This was accompanied by a restoration of eNOS expression and plasma NOx in hypertensive rats. The results demonstrated that the phytochemical components of the CT extract were mainly comprised of flavonoids, including kaempferol 3-glucoside, quercetin 3-rhamnosyl-rhamnosyl-glucoside, rutin, quercetin 3-glucoside, and kaempferol 3-isorhamninoside. It is possible that these flavonoids exerted biological activities to scavenge oxidative stress and, subsequently, raise NO bioavailability. The CT extract possesses antioxidant capacity through its DPPH radical scavenging activity, total polyphenolic and flavonoid contents, and ferric reducing antioxidant power [51]. There is substantial evidence showing that flavonoids have beneficial effects on lowering blood pressure by reducing endothelial cell oxidative stress and increasing NO bioavailability [52]. The present study showed an alleviation of oxidative damage in CT extract-treated rats mediated by reduced vascular $\mathrm{O}_{2}{ }^{--}$production and (plasma and tissue) MDA levels, resulting in increased NO bioavailability, as well as increased eNOS protein expression, in LV tissue.

RAS activation might be one of the possible mechanisms increasing blood pressure and oxidative stress in L-NAME rats. L-NAME hypertensive rats showed high levels of $\mathrm{ACE}$ activity, plasma Ang II, and upregulation of $\mathrm{AT}_{1} \mathrm{R}$ protein expression. These results are supported by the fact that renal ACE producing Ang II is necessary for L-NAME-induced hypertension [53]. Furthermore, Ang II-induced oxidative stress through binding on $\mathrm{AT}_{1} \mathrm{R}$ and the subsequent activation of NADPH oxidase subunits to generate $\mathrm{O}_{2}{ }^{\bullet-}$ has been described [13] in L-NAME-induced hypertension. We found an overexpression of NOX2 in cardiac tissue, which might be responsible for the production of reactive oxygen species in these hypertensive rats. CT extract treatment suppressed RAS activation by reducing serum ACE activity and Ang II generation in L-NAME-treated rats. Such RAS inhibition 
might contribute to its blood pressure lowering and vasoprotective effects. Our results were supported by another study, in which the inhibitory effects of CT petal extract on ACE activity were observed to mediate its antihypertensive effect [54].

$\mathrm{LV}$ dysfunction and hypertrophy were found in rats under long-term exposure to high blood pressure induced by L-NAME. The LV hypertrophy was supported by increased LVW/BW ratio, LVIDd, and LVPWd, while LV dysfunction was characterized by decreasing SV, \%EF, and \%FS. The impairment of LV contraction in L-NAME rats in the present study was consistent with the results of a previous study that rats receiving L-NAME had cardiac morphology and dysfunction, as evidenced by increases in IVSd, IVSs, and LVWd, as well as decreases in LVIDd, EDV, \%EF, SV, and \%FS [5]. These cardiac disruptions induced by L-NAME were alleviated in rats treated with CT extract. This might suggest that the cardioprotective effects of CT extract in the present study are likely relevant to its beneficial effects on blood pressure, vascular function, oxidative stress, and RAS activation. Additionally, the molecular mechanisms involved in the effect of CT extract on cardiac abnormalities were revealed, as associated with inflammation through the Ang $\mathrm{II} / \mathrm{AT}_{1} \mathrm{R} / \mathrm{NOX} 2 / \mathrm{NF}-\mathrm{kB}$ pathway. We found that the elevated NF- $\mathrm{kB}$ expression and TNF- $\alpha$ in the cardiac tissue of hypertensive rats were suppressed in CT extract-treated rats. Several studies have described that the activation of the NF- $\mathrm{kB}$ signaling pathway is required for the hypertrophic growth of cardiomyocytes [22,55]. Ang II-induced ROS production leading to the activation of NF- $\mathrm{KB}$ and inflammation has been well-described [16]. Furthermore, the preventive effects of $\mathrm{CT}$ extract on lipopolysaccharide-induced inflammation in macrophage cells have been shown [56].

Lisinopril has been widely recommended for hypertension treatment. It reduces blood pressure through the inhibition of ACE activity [57]. Our results showed that lisinopril prevented L-NAME-induced hypertension, improved LV and vascular function, and suppressed oxidative stress and the Ang II/ $\mathrm{AT}_{1} \mathrm{R} / \mathrm{NOX} 2 / \mathrm{NF}-\mathrm{kB}$ pathway. In addition to reducing ACE activity, lisinopril has been shown to possess other beneficial effects, such as antioxidation, anti-inflammation, and cardiovascular protection [37,58-60].

\section{Conclusions}

In conclusion, CT extract and lisinopril prevented the L-NAME-induced development of hypertension and, therefore, were associated with the alleviation of cardiovascular dysfunction in rats. These effects were associated with the suppression of RAS activation, oxidative stress, and inflammation due to the modulation of the $\mathrm{AT}_{1} \mathrm{R} / \mathrm{NOX} 2 / \mathrm{NF}-\mathrm{kB}$ pathway.

Author Contributions: Conceptualization, P.M. and P.P. (Poungrat Pakdeechote); methodology, M.I., N.C., and A.P.; formal analysis, M.I., S.R., and P.M.; investigation, P.P. (Prapassorn Potue), S.B., P.C., and P.P. (Poungrat Pakdeechote); writing—original draft preparation, P.M.; writing-review and editing, P.P. (Poungrat Pakdeechote) All authors have read and agreed to the published version of the manuscript.

Funding: This work was financially supported by the Young Researcher Development Project of Khon Kaen University, Khon Kaen, Thailand and Research Program, Khon Kaen University, Khon Kaen, Thailand.

Institutional Review Board Statement: The study was conducted according to the guidelines for Care and Use of Laboratory Animals of Khon Kaen University, and approved by the Animal Ethics Committee of Khon Kaen University, Khon Kaen, Thailand (AEKKU-NELAC 72/2561).

Informed Consent Statement: Not applicable.

Data Availability Statement: No new data were created or analyzed in this study.

Conflicts of Interest: The authors declare no conflict of interest. 


\section{References}

1. Furchgott, R.F.; Zawadzki, J.V. The obligatory role of endothelial cells in the relaxation of arterial smooth muscle by acetylcholine. Nature 1980, 288, 373-376. [CrossRef] [PubMed]

2. Barrows, I.R.; Ramezani, A.; Raj, D.S. Inflammation, Immunity, and Oxidative Stress in Hypertension-Partners in Crime? Adv. Chronic Kidney Dis. 2019, 26, 122-130. [CrossRef]

3. Ribeiro, M.O.; Antunes, E.; de Nucci, G.; Lovisolo, S.M.; Zatz, R. Chronic inhibition of nitric oxide synthesis. A new model of arterial hypertension. A new model of arterial hypertension. Hypertension 1992, 20, 298-303. [CrossRef]

4. Pechanova, O.; Bernatova, I.; Babal, P.; Martinez, M.C.; Kysela, S.; Stvrtina, S.; Andriantsitohaina, R. Red wine polyphenols prevent cardiovascular alterations in L-NAME-induced hypertension. J. Hypertens. 2004, 22, 1551-1559. [CrossRef]

5. Wunpathe, C.; Maneesai, P.; Rattanakanokchai, S.; Bunbupha, S.; Kukongviriyapan, U.; Tong-Un, T.; Pakdeechote, P. Tangeretin mitigates 1-NAME-induced ventricular dysfunction and remodeling through the AT1R/pERK1/2/pJNK signaling pathway in rats. Food Funct. 2020, 11, 1322-1333. [CrossRef]

6. Bunbupha, S.; Pakdeechote, P.; Maneesai, P.; Prachaney, P.; Boonprom, P. Carthamus Tinctorius L. extract attenuates cardiac remodeling in L-NAME-induced hypertensive rats by inhibiting the NADPH oxidase-mediated TGF-beta1 and MMP-9 pathway. Ann. Anat. Anat. Anz. 2019, 222, 120-128. [CrossRef]

7. Seth, M.K.; Hussain, M.E.; Pasha, S.; Fahim, M. Effects of a novel ACE inhibitor, 3-(3-thienyl)-l-alanyl-ornithyl-proline, on endothelial vasodilation and hepatotoxicity in 1-NAME-induced hypertensive rats. Drug Des. Devel. Ther. 2016, 10, 1533-1542. [CrossRef]

8. Takemoto, M.; Egashira, K.; Usui, M.; Numaguchi, K.; Tomita, H.; Tsutsui, H.; Shimokawa, H.; Sueishi, K.; Takeshita, A. Important role of tissue angiotensin-converting enzyme activity in the pathogenesis of coronary vascular and myocardial structural changes induced by long-term blockade of nitric oxide synthesis in rats. J. Clin. Investig. 1997, 99, 278-287. [CrossRef] [PubMed]

9. Ferrario, C.M. Cardiac remodelling and RAS inhibition. Ther. Adv. Cardiovasc. Dis. 2016, 10, 162-171. [CrossRef]

10. Sankar, D.; Rao, M.R.; Sambandam, G.; Pugalendi, K.V. Effect of sesame oil on diuretics or Beta-blockers in the modulation of blood pressure, anthropometry, lipid profile, and redox status. Yale J. Biol. Med. 2006, 79, 19-26.

11. Rodríguez-Rodríguez, P.; López de Pablo, A.L.; García-Prieto, C.F.; Somoza, B.; Quintana-Villamandos, B.; Gómez de Diego, J.J.; Gutierrez-Arzapalo, P.Y.; Ramiro-Cortijo, D.; González, M.C.; Arribas, S.M. Long term effects of fetal undernutrition on rat heart. Role of hypertension and oxidative stress. PLoS ONE 2017, 12, e0171544. [CrossRef]

12. Sato, N.; Kase, H.; Kato, T.; Kasai, K. Effect of angiotensin II type 1 receptor antagonist on oxidative stress markers in type 2 diabetic patients with hypertension. Nihon Rinsho Jpn. J. Clin. Med. 2003, 61, 1245-1249.

13. Rincón, J.; Correia, D.; Arcaya, J.L.; Finol, E.; Fernández, A.; Pérez, M.; Yaguas, K.; Talavera, E.; Chávez, M.; Summer, R.; et al. Role of Angiotensin II type 1 receptor on renal NAD $(\mathrm{P}) \mathrm{H}$ oxidase, oxidative stress and inflammation in nitric oxide inhibition induced-hypertension. Life Sci. 2015, 124, 81-90. [CrossRef] [PubMed]

14. Brandes, R.P.; Kreuzer, J. Vascular NADPH oxidases: Molecular mechanisms of activation. Cardiovasc. Res. 2005, 65, 16-27. [CrossRef] [PubMed]

15. Jung, O.; Schreiber, J.G.; Geiger, H.; Pedrazzini, T.; Busse, R.; Brandes, R.P. gp91phox-containing NADPH oxidase mediates endothelial dysfunction in renovascular hypertension. Circulation 2004, 109, 1795-1801. [CrossRef]

16. Garrido, A.M.; Griendling, K.K. NADPH oxidases and angiotensin II receptor signaling. Mol. Cell. Endocrinol. 2009, 302, 148-158. [CrossRef]

17. Bunbupha, S.; Pakdeechote, P.; Kukongviriyapan, U.; Prachaney, P.; Kukongviriyapan, V. Asiatic acid reduces blood pressure by enhancing nitric oxide bioavailability with modulation of eNOS and p47phox expression in L-NAME-induced hypertensive rats. Phytother. Res. 2014, 28, 1506-1512. [CrossRef]

18. Maneesai, P.; Prasarttong, P.; Bunbupha, S.; Kukongviriyapan, U.; Kukongviriyapan, V.; Tangsucharit, P.; Prachaney, P.; Pakdeechote, P. Synergistic Antihypertensive Effect of Carthamus tinctorius L. Extract and Captopril in L-NAME-Induced Hypertensive Rats via Restoration of eNOS and AT(1)R Expression. Nutrients 2016, 8, 122. [CrossRef] [PubMed]

19. Bertera, F.M.; Santa-Cruz, D.M.; Balestrasse, K.B.; Gorzalczany, S.B.; Höcht, C.; Taira, C.A.; Polizio, A.H. Tempol-nebivolol therapy potentiates hypotensive effect increasing NO bioavailability and signaling pathway. Free Radic. Res. 2014, 48, 109-118. [CrossRef]

20. Li, H.; Witte, K.; August, M.; Brausch, I.; Gödtel-Armbrust, U.; Habermeier, A.; Closs, E.I.; Oelze, M.; Münzel, T.; Förstermann, U. Reversal of endothelial nitric oxide synthase uncoupling and up-regulation of endothelial nitric oxide synthase expression lowers blood pressure in hypertensive rats. J. Am. Coll. Cardiol. 2006, 47, 2536-2544. [CrossRef]

21. Soliman, E.; Behairy, S.F.; El-Maraghy, N.N.; Elshazly, S.M. PPAR- $\gamma$ agonist, pioglitazone, reduced oxidative and endoplasmic reticulum stress associated with L-NAME-induced hypertension in rats. Life Sci. 2019, 239, 117047. [CrossRef] [PubMed]

22. Purcell, N.H.; Tang, G.; Yu, C.; Mercurio, F.; DiDonato, J.A.; Lin, A. Activation of NF-kappa B is required for hypertrophic growth of primary rat neonatal ventricular cardiomyocytes. Proc. Natl. Acad. Sci. USA 2001, 98, 6668-6673. [CrossRef]

23. Crowley, S.D. Linking angiotensin II to nuclear factor-kappa light chain enhancer of activated B cells-induced cardiovascular damage: Bad CARMAs. Hypertension 2014, 64, 933-934. [CrossRef]

24. Lee, C.Y.; Park, H.K.; Lee, B.S.; Jeong, S.; Hyun, S.A.; Choi, J.W.; Kim, S.W.; Lee, S.; Lim, S.; Hwang, K.C. Novel Therapeutic Effects of Pterosin B on Ang II-Induced Cardiomyocyte Hypertrophy. Molecules 2020, 25, 5279. [CrossRef]

25. Kosutova, M.; Pechanova, O.; Barta, A.; Franova, S.; Cebova, M. Different adaptive NO-dependent Mechanisms in Normal and Hypertensive Conditions. Molecules 2019, 24, 1682. [CrossRef] [PubMed] 
26. Maneesai, P.; Bunbupha, S.; Potue, P.; Berkban, T.; Kukongviriyapan, U.; Kukongviriyapan, V.; Prachaney, P.; Pakdeechote, P. Hesperidin Prevents Nitric Oxide Deficiency-Induced Cardiovascular Remodeling in Rats via Suppressing TGF-beta1 and MMPs Protein Expression. Nutrients 2018, 10, 1549. [CrossRef] [PubMed]

27. Chayaratanasin, P.; Caobi, A.; Suparpprom, C.; Saenset, S.; Pasukamonset, P.; Suanpairintr, N.; Barbieri, M.A.; Adisakwattana, S. Clitoria ternatea Flower Petal Extract Inhibits Adipogenesis and Lipid Accumulation in 3T3-L1 Preadipocytes by Downregulating Adipogenic Gene Expression. Molecules 2019, 24, 1894. [CrossRef]

28. Chayaratanasin, P.; Barbieri, M.A.; Suanpairintr, N.; Adisakwattana, S. Inhibitory effect of Clitoria ternatea flower petal extract on fructose-induced protein glycation and oxidation-dependent damages to albumin in vitro. BMC Complement. Altern. Med. 2015, 15, 27. [CrossRef]

29. Escher, G.B.; Wen, M.; Zhang, L.; Rosso, N.D.; Granato, D. Phenolic composition by UHPLC-Q-TOF-MS/MS and stability of anthocyanins from Clitoria ternatea L. (butterfly pea) blue petals. Food Chem. 2020, 331, 127341. [CrossRef] [PubMed]

30. Kamkaen, N.; Wilkinson, J.M. The antioxidant activity of Clitoria ternatea flower petal extracts and eye gel. Phytother. Res. 2009, 23, 1624-1625. [CrossRef] [PubMed]

31. Mukherjee, P.K.; Kumar, V.; Kumar, N.S.; Heinrich, M. The Ayurvedic medicine Clitoria ternatea-from traditional use to scientific assessment. J. Ethnopharmacol. 2008, 120, 291-301. [CrossRef] [PubMed]

32. Eliza, J.; Daisy, P.; Ignacimuthu, S.; Duraipandiyan, V. Antidiabetic and antilipidemic effect of eremanthin from Costus speciosus (Koen.)Sm., in STZ-induced diabetic rats. Chem. Biol. Interact. 2009, 182, 67-72. [CrossRef]

33. Oguis, G.K.; Gilding, E.K.; Jackson, M.A.; Craik, D.J. Butterfly Pea (Clitoria ternatea), a Cyclotide-Bearing Plant With Applications in Agriculture and Medicine. Front. Plant Sci. 2019, 10, 645. [CrossRef]

34. Phrueksanan, W.; Yibchok-anun, S.; Adisakwattana, S. Protection of Clitoria ternatea flower petal extract against free radicalinduced hemolysis and oxidative damage in canine erythrocytes. Res. Vet. Sci. 2014, 97, 357-363. [CrossRef] [PubMed]

35. Chusak, C.; Thilavech, T.; Henry, C.J.; Adisakwattana, S. Acute effect of Clitoria ternatea flower beverage on glycemic response and antioxidant capacity in healthy subjects: A randomized crossover trial. BMC Complement. Altern. Med. 2018, 18, 6. [CrossRef]

36. Pakdeechote, P.; Rummery, N.M.; Ralevic, V.; Dunn, W.R. Raised tone reveals purinergic-mediated responses to sympathetic nerve stimulation in the rat perfused mesenteric vascular bed. Eur. J. Pharmacol. 2007, 563, 180-186. [CrossRef] [PubMed]

37. Poasakate, A.; Maneesai, P.; Rattanakanokchai, S.; Bunbupha, S.; Tong-Un, T.; Pakdeechote, P. Genistein Prevents Nitric Oxide Deficiency-Induced Cardiac Dysfunction and Remodeling in Rats. Antioxidants 2021, 10, 237. [CrossRef]

38. Maneesai, P.; Bunbupha, S.; Kukongviriyapan, U.; Senggunprai, L.; Kukongviriyapan, V.; Prachaney, P.; Pakdeechote, P. Effect of asiatic acid on the Ang II-AT1R-NADPH oxidase-NF-kappaB pathway in renovascular hypertensive rats. Naunyn-Schmiedeberg's Arch. Pharmacol. 2017, 390, 1073-1083. [CrossRef]

39. Pakdeechote, P.; Meephat, S.; Sakonsinsiri, C.; Phetcharaburanin, J.; Bunbupha, S.; Maneesai, P. Syzygium gratum Extract Alleviates Vascular Alterations in Hypertensive Rats. Medicina 2020, 56, 509. [CrossRef]

40. Potue, P.; Wunpathe, C.; Maneesai, P.; Kukongviriyapan, U.; Prachaney, P.; Pakdeechote, P. Nobiletin alleviates vascular alterations through modulation of Nrf-2/HO-1 and MMP pathways in l-NAME induced hypertensive rats. Food Funct. 2019, 10, 1880-1892. [CrossRef]

41. Sharma, D.K.; Manral, A.; Saini, V.; Singh, A.; Srinivasan, B.P.; Tiwari, M. Novel diallyldisulfide analogs ameliorate cardiovascular remodeling in rats with L-NAME-induced hypertension. Eur. J. Pharmacol. 2012, 691, 198-208. [CrossRef] [PubMed]

42. Silambarasan, T.; Manivannan, J.; Krishna Priya, M.; Suganya, N.; Chatterjee, S.; Raja, B. Sinapic acid prevents hypertension and cardiovascular remodeling in pharmacological model of nitric oxide inhibited rats. PLoS ONE 2014, 9, e115682. [CrossRef] [PubMed]

43. Pechanova, O.; Vrankova, S.; Cebova, M. Chronic L-Name-Treatment Produces Hypertension by Different Mechanisms in Peripheral Tissues and Brain: Role of Central eNOS. Pathophysiology 2020, 27, 46-54. [CrossRef]

44. Kolo, L.L.; Westfall, T.C.; Macarthur, H. Nitric oxide decreases the biological activity of norepinephrine resulting in altered vascular tone in the rat mesenteric arterial bed. Am. J. Physiol. Heart Circ. Physiol. 2004, 286, H296-H303. [CrossRef]

45. Vrankova, S.; Zemancikova, A.; Torok, J.; Pechanova, O. Effect of low dose L-NAME pretreatment on nitric oxide/reactive oxygen species balance and vasoactivity in L-NAME/salt-induced hypertensive rats. J. Physiol. Pharmacol. 2019, 70. [CrossRef]

46. Pryor, W.A.; Squadrito, G.L. The chemistry of peroxynitrite: A product from the reaction of nitric oxide with superoxide. Am. J. Physiol. Lung Cell. Mol. Physiol. 1995; 268, L699-L722.

47. Junqueira, V.B.; Simizu, K.; Videla, L.A.; Silvia, B.D.M. Dose-dependent study of the effects of acute lindane administration on rat liver superoxide anion production, antiooidant enzyme activities and lipid peroxidation. Toxicology 1986, 41, 193-204. [CrossRef]

48. Llesuy, S.; Milei, J.; Picone, V.; Flecha, B.G.; Beigelman, R.; Boveris, A. Effect of vitamins A and E on ischemia-reperfusion damage in rabbit heart. Mol. Cell. Biochem. 1995, 145, 45-51. [CrossRef] [PubMed]

49. Escobar, J.; Rubio, M.; Lissi, E. SOD and catalase inactivation by singlet oxygen and peroxyl radicals. Free Radic. Biol. Med. 1996, 20, 285-290. [CrossRef]

50. Shimizu, N.; Kobayashi, K.; Hayashi, K. The reaction of superoxide radical with catalase. Mechanism of the inhibition of catalase by superoxide radical. Mechanism of the inhibition of catalase by superoxide radical. J. Biol. Chem. 1984, 259, 4414-4418.

51. Lakshan, S.A.T.; Jayanath, N.Y.; Abeysekera, W.; Abeysekera, W. A Commercial Potential Blue Pea (Clitoria ternatea L.) Flower Extract Incorporated Beverage Having Functional Properties. Evid. Based Complement. Altern. Med. 2019, 20. [CrossRef] 
52. Maaliki, D.; Shaito, A.A.; Pintus, G.; El-Yazbi, A.; Eid, A.H. Flavonoids in hypertension: A brief review of the underlying mechanisms. Curr. Opin. Pharmacol. 2019, 45, 57-65. [CrossRef]

53. Giani, J.F.; Shah, K.H.; Khan, Z.; Bernstein, E.A.; Shen, X.Z.; McDonough, A.A.; Gonzalez-Villalobos, R.A.; Bernstein, K.E. The intrarenal generation of angiotensin II is required for experimental hypertension. Curr. Opin. Pharmacol. 2015, $21,73-81$. [CrossRef] [PubMed]

54. Escher, G.B.; Marques, M.B.; do Carmo, M.A.V.; Azevedo, L.; Furtado, M.M.; Sant'Ana, A.S.; da Silva, M.C.; Genovese, M.I.; Wen, M.; Zhang, L.; et al. Clitoria ternatea L. petal bioactive compounds display antioxidant, antihemolytic and antihypertensive effects, inhibit $\alpha$-amylase and $\alpha$-glucosidase activities and reduce human LDL cholesterol and DNA induced oxidation. Food Res. Int. 2020, 128, 108763. [CrossRef]

55. Yamamoto, K.; Shioi, T.; Uchiyama, K.; Miyamoto, T.; Sasayama, S.; Matsumori, A. Attenuation of virus-induced myocardial injury by inhibition of the angiotensin II type 1 receptor signal and decreased nuclear factor-kappa B activation in knockout mice. J. Am. Coll. Cardiol. 2003, 42, 2000-2006. [CrossRef] [PubMed]

56. Nair, V.; Bang, W.Y.; Schreckinger, E.; Andarwulan, N.; Cisneros-Zevallos, L. Protective Role of Ternatin Anthocyanins and Quercetin Glycosides from Butterfly Pea (Clitoria ternatea Leguminosae) Blue Flower Petals against Lipopolysaccharide (LPS)Induced Inflammation in Macrophage Cells. J. Agric. Food Chem. 2015, 63, 6355-6365. [CrossRef]

57. Thind, G.S. Angiotensin converting enzyme inhibitors: Comparative structure, pharmacokinetics, and pharmacodynamics. Cardiovasc. Drugs Ther. 1990, 4, 199-206. [CrossRef] [PubMed]

58. Yamada, T.; Kuno, A.; Masuda, K.; Ogawa, K.; Sogawa, M.; Nakamura, S.; Ando, T.; Sano, H.; Nakazawa, T.; Ohara, H.; et al. Candesartan, an angiotensin II receptor antagonist, suppresses pancreatic inflammation and fibrosis in rats. J. Pharmacol. Exp. Ther. 2003, 307, 17-23. [CrossRef] [PubMed]

59. Saber, S.; Goda, R.; El-Tanbouly, G.S.; Ezzat, D. Lisinopril inhibits nuclear transcription factor kappa B and augments sensitivity to silymarin in experimental liver fibrosis. Int. Immunopharmacol. 2018, 64, 340-349. [CrossRef]

60. Jan-On, G.; Sangartit, W.; Pakdeechote, P.; Kukongviriyapan, V.; Sattayasai, J.; Senaphan, K.; Kukongviriyapan, U. Virgin rice bran oil alleviates hypertension through the upregulation of eNOS and reduction of oxidative stress and inflammation in L-NAME-induced hypertensive rats. Nutrition 2020, 69, 110575. [CrossRef] [PubMed] 